\title{
Production and Characterization of Cross-Linked Aggregates of Geobacillus thermoleovorans CCR11 Thermoalkaliphilic Recombinant Lipase
}

\author{
Rosa-María Oliart-Ros ${ }^{1}$, Giselle-Lilian Badillo-Zeferino ${ }^{1} @$, Rodolfo Quintana-Castro ${ }^{2}{ }^{\mathbb{D}}$, \\ Irving-Israel Ruíz-López ${ }^{3}$, Alfonso Alexander-Aguilera ${ }^{2}{ }^{\circledR}$, Jorge-Guillermo Domínguez-Chávez ${ }^{2}$, \\ Azmat Ali Khan ${ }^{4}\left(\mathbb{D}\right.$, Dinh Duc Nguyen ${ }^{5,6}$, Ashok Kumar Nadda $7, * \mathbb{1}$ and María-Guadalupe Sánchez-Otero ${ }^{2, * \mathbb{C}}$
}

check for

updates

Citation: Oliart-Ros, R.-M.; BadilloZeferino, G.-L.; Quintana-Castro, R.; Ruíz-López, I.-I.; Alexander-Aguilera, A.; Domínguez-Chávez, J.-G.; Khan, A.A.; Nguyen, D.D.; Nadda, A.K.; Sánchez-Otero, M.-G. Production and Characterization of Cross-Linked Aggregates of Geobacillus thermoleovorans CCR11

Thermoalkaliphilic Recombinant Lipase. Molecules 2021, 26, 7569 https://doi.org/10.3390/ molecules26247569

Academic Editors: Alicia Prieto and Claudiu T. Supuran

Received: 3 October 2021

Accepted: 16 November 2021

Published: 14 December 2021

Publisher's Note: MDPI stays neutra with regard to jurisdictional claims in published maps and institutional affiliations.

Copyright: (c) 2021 by the authors. Licensee MDPI, Basel, Switzerland. This article is an open access article distributed under the terms and conditions of the Creative Commons Attribution (CC BY) license (https:/ / creativecommons.org/licenses/by/ $4.0 /)$.
1 Unidad de Investigación y Desarrollo en Alimentos, Tecnológico Nacional de México, Instituto Tecnológico de Veracruz, M.A. De Quevedo 2779, Veracruz C.P. 91897, Ver., Mexico; rosa.or@veracruz.tecnm.edu.mx (R.-M.O.-R.); gbadizef@gmail.com (G.-L.B.-Z.)

2 Facultad de Bioanálisis, Universidad Veracruzana, Carmen Serdán Esq. Iturbide, Veracruz C.P. 91700, Ver., Mexico; roquintana@uv.mx (R.Q.-C.); aalexander@uv.mx (A.A.-A.); jorgedominguez@uv.mx (J.-G.D.-C.)

3 Facultad de Ingeniería Química, Benemérita Universidad Autónoma de Puebla, Av. San Claudio y 18 Sur, Ciudad Universitaria, Puebla C.P. 72570, Pue., Mexico; irving.ruiz@correo.buap.mx

4 Pharmaceutical Biotechnology Laboratory, Department of Pharmaceutical Chemistry, College of Pharmacy, King Saud University, Riyadh 11451, Saudi Arabia; azkhan@ksu.edu.sa

5 Department of Environmental and Energy Engineering, Kyonggi University, 154-42 Gwanggyosan-ro, Yeongtong-gu, Suwon-si 16227, Gyeonggi-do, Korea; dinhduc.nguyen@kyonggi.ac.kr

6 Faculty of Environmental and Food Engineering, Nguyen Tat Thanh University, 300A Nguyen Tat Thanh, District 4, Ho Chi Minh City 755414, Vietnam

7 Department of Biotechnology and Bioinformatics, Faculty of Biotechnology, Jaypee University of Information Technology, Waknaghat, Solan, Himachal Pradesh 173 234, India

* Correspondence: ashok.nadda09@gmail.com (A.K.N.); guadsanchez@uv.mx (M.-G.S.-O.); Tel.: +91-017-9223-9353 (A.K.N.); +55-229-932-1707 (M.-G.S.-O.)

Abstract: Immobilization of enzymes has many advantages for their application in biotechnological processes. In particular, the cross-linked enzyme aggregates (CLEAs) allow the production of solid biocatalysts with a high enzymatic loading and the advantage of obtaining derivatives with high stability at low cost. The purpose of this study was to produce cross-linked enzymatic aggregates (CLEAs) of LipMatCCR11, a $43 \mathrm{kDa}$ recombinant solvent-tolerant thermoalkaliphilic lipase from Geobacillus thermoleovorans CCR11. LipMatCCR11-CLEAs were prepared using $\left(\mathrm{NH}_{4}\right)_{2} \mathrm{SO}_{4}(40 \% w / v)$ as precipitant agent and glutaraldehyde $(40 \mathrm{mM})$ as cross-linker, at $\mathrm{pH} 9,20{ }^{\circ} \mathrm{C}$. A $\mathrm{U}_{10}\left(5^{6}\right)$ uniform design was used to optimize CLEA production, varying protein concentration, ammonium sulfate $\%$, $\mathrm{pH}$, glutaraldehyde concentration, temperature, and incubation time. The synthesized CLEAs were also analyzed using scanning electron microscopy (SEM) that showed individual particles of $<1 \mu \mathrm{m}$ grouped to form a superstructure. The cross-linked aggregates showed a maximum mass activity of $7750 \mathrm{U} / \mathrm{g}$ at $40{ }^{\circ} \mathrm{C}$ and $\mathrm{pH} 8$ and retained more than $20 \%$ activity at $100{ }^{\circ} \mathrm{C}$. Greater thermostability, resistance to alkaline conditions and the presence of organic solvents, and better durability during storage were observed for LipMatCCR11-CLEAs in comparison with the soluble enzyme. LipMatCCR11-CLEAs presented good reusability by conserving $40 \%$ of their initial activity after 9 cycles of reuse.

Keywords: cross-linked enzymatic aggregates (CLEAs); thermoalkaliphilic lipase; Geobacillus thermoleovorans

\section{Introduction}

Lipases (E.C. 3.1.1.3) are ubiquitous enzymes, as they have been found to occur in most living organisms; in vivo, they catalyze the hydrolysis of triacylglycerides to glycerol 
and fatty acids [1]. In non-aqueous media, lipases can synthesize a wide range of esters or compounds with analogous bonding as amides; due to these features, lipases are widely applied in many industrial areas, such as the food industry, the production of biopharmaceuticals, biofuels, biopolymers, and detergents [2-5].

Lipases share common structural features such as the canonical $\alpha / \beta$ hydrolase fold, the catalytic triad, and the oxyanion hole [6,7]. Some of them possess a flexible alphahelix (called "lid") covering their active site, which in its "closed conformation" makes it inaccessible to substrates; this form exists in equilibrium with an "open form". However, in the presence of hydrophobic interfaces, the equilibrium between the open and closed forms shifts to the "open form" through important conformational changes, where the active site becomes accessible and hydrophobic surfaces are exposed, increasing enzyme activity, a phenomenon called interfacial activation. This phenomenon is very important for all applications of lipases [8,9]. Thermoalkaliphilic lipases are particularly interesting due to their high stability towards high temperatures and $\mathrm{pH}$, chaotropic agents, detergents, and some protease activity $[1,6,10]$.

Immobilization of enzymes has many advantages since it allows the recovery and reuse of biocatalysts, improves reaction control, and generally has a positive impact on thermal stability as well as the stability in the presence of organic solvents and other chaotropic agents, and can improve the resistance to drastic $\mathrm{pH}$ values; immobilization also facilitates the separation of products and avoids contamination by the enzyme; therefore, immobilization is a key factor in the establishment of novel lipase applications and expansion of the current ones. Since there are many factors that are involved to achieve a successful immobilization of an enzyme, it is necessary to explore different methods in order to improve the enzyme stability, specificity, selectivity, and general performance [11-17].

In the traditional methods of immobilization, a solid support is used to bind the enzyme, which provides mechanical resistance and protection from direct heat shock [11-15,17-20]. In this context, the production of cross-linked enzyme aggregates (CLEAs) has proven to be an important immobilization technique that allows the production of solid biocatalysts with a high enzymatic loading and the advantage of obtaining derivatives with higher stability than their soluble counterparts and reducing costs, as there are no carrier expenses [20-22]. CLEA preparation might be achieved using different precipitants and cross-linkers; although it is supposed to be a simple technology, there are many experimental factors involved that may affect the particle size, stability, and catalytic capabilities of the final product; also, the size and solubility of the substrates might not be fully compatible with the pore size of resultant CLEAs, decreasing the activity since only the enzymes on the surface of the aggregate are catalytically active $[16,20]$. The synthesis of CLEAs involves the covalent cross-linking of a precipitated enzyme; the precipitation is achieved by adding agents such as polymers, inorganic salts, and organic solvents; among them, inorganic salts and polymers are preferred for CLEA synthesis as they promote the formation of aggregates without affecting the three-dimensional structure of the proteins $[23,24]$. To fix the network permanently after precipitation, intermolecular unions are formed by using bifunctional reagents, such as diiminoesters, dihydrins and diamines [20,25], and most recently, sodium tripolyphosphate [26]. In this regard, the most used cross-linking agent is glutaraldehyde, which can react with several functional groups of proteins, including thiol, phenol, and imidazole, but preferably with the $\varepsilon$-amino groups found, for example, in the side group of lysines. In aqueous medium, glutaraldehyde has a strong tendency to self-polymerize, depending on its concentration and medium $\mathrm{pH}$. Alkaline conditions promote self-polymerization, while acidic conditions decrease self-polymerization and enhance glutaraldehyde stability. The mechanism is generally not limited to a single reaction, since it depends on different trigger points such as polymerization products or reaction products with different functional groups [27]; ideally the lysines located in the surface of the enzyme react with one of the aldehyde extremes, giving rise to a first Schiff base; then, the free aldehyde group can establish a covalent bond with another enzyme molecule [25]. The result of the reticulation process is a network of 
enzymes with irreversible intermolecular bonds capable of withstanding harsh conditions of $\mathrm{pH}$ and temperature, although the reaction might be incomplete at the interior of the aggregate, affecting the final stability of the solid enzyme $[20,25,27]$. Since the initial step of precipitation could be considered a form of purification, the process can be efficiently used with cell lysates or fermentation broths [20,28].

One of the most important objectives of an enzyme's immobilization is to improve its storage and reusability, which provides opportunities for several cycles of biocatalysis. Some authors have addressed these properties in CLEAs of different enzymes such as a serine hydroxyl methyltransferase from Idiomerina leihiensis [12], a lipase from Rhizopus oryzae [29], or a lipase from Candida rugosa [30]. Reusability assays have demonstrated around 10 cycles of use, followed by a loss of activity due to mechanical forces and leaching or to denaturation of the enzyme [24]

Regarding the synthesis of CLEAs of lipolytic enzymes, the literature includes agents such as tert-butyl alcohol (50-90\% v/v) and ammonium sulfate (20-60\% saturation) among the more-used compounds for inducing precipitation [31]; in other hydrolases, other agents have been reported such as cooled acetone (100\%) as an effective precipitant for a thermostable xylanase [22]. Other reaction conditions (precipitation time, $\mathrm{pH}$, temperature, agitation, incubation time, protein source, use of additives) can also be modified to obtain a product with the desired characteristics [23,24]; therefore, the study of the cross-linking conditions is a mandatory step in the synthesis of CLEAs of any enzyme. With respect to the stability of CLEAs of lipases, there are reports of increased thermostability in CLEAs prepared with commercial lipases such as Candida antarctica lipase B (CALB-L), Thermomyces lanuginosa lipase, C. rugosa lipase, and Rhizopus delemar lipase using PEGs and acetone as precipitants [32].

In a previous study, the thermoalkaliphilic lipase LipMatCCR11 from Geobacillus thermoleovorans CCR11 was expressed in Escherichia coli [33]. A 43 kDa enzyme, LipMatCCR11 has 11 lysine residues in its structure, none of which is directly involved with the active site or the domains of interaction with $\mathrm{Ca}^{+2}$ and $\mathrm{Zn}^{+2}$, two of the Lys residues located in the lid region. In a previous study, LipMatCCR11 was used in lyophilized form for the synthesis of flavors and fragrance esters with hexane as a reaction medium [3]. Later, using response surface methodology, conditions for maximum expression were investigated and a 1300-fold increase in lipolytic activity was achieved; this enzyme was also immobilized in Accurel EP-100 and used to synthetize aromatic esters [34]. The aims of the present work were to establish the best conditions to produce cross-linked aggregates of the recombinant thermoalkaliphilic lipase LipMatCCR1 using ammonium sulfate as precipitation agent and glutaraldehyde as cross-linking agent, and to characterize the immobilized product.

\section{Results and Discussion}

\subsection{Optimization of LipMatCCR11-CLEA Production}

For LipMatCCR11-CLEA preparation, glutaraldehyde was selected as the reticulant agent since LipMatCCR11 has 11 lysine residues in its structure, none of which is directly involved in the active site or the domains of interaction with $\mathrm{Ca}^{+2}$ and $\mathrm{Zn}^{+2}$ (Figure 1A). By comparison with the Geobacillus thermocatenulatus lipase [6], it was assumed that the residues Lys182 and Lys226 in LipMatCCR11 might be involved in the salt bridges that are destabilized when the lid is opened, and in consequence, could participate in the cross-linking process with aldehyde groups, promoting an artificial opening of the lid (Figure 1B).

Optimization of the synthesis of CLEAs using experimental design strategies and statistical data management is a relatively recent field of study [28]. The most frequently used experimental designs for this purpose are full factorial designs, which are robust and straightforward in approach; however, with this type of design, a limited number of variables and levels can be considered [24,37-39]. In the present work, a $\mathrm{U}_{10}\left(5^{6}\right)$ uniform design allowed us to assess the effect of 6 factors in 5 levels. 


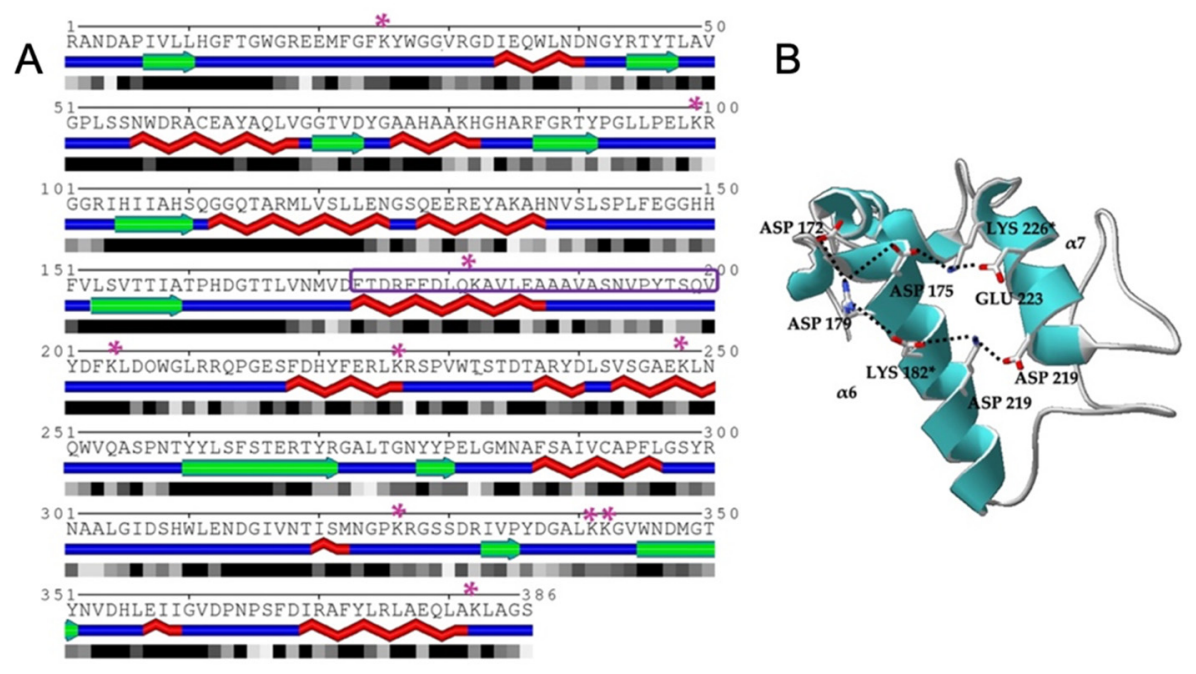

Figure 1. (A) Expected secondary structures based on the amino acid sequence of the LipMatCCR11 lipase are depicted; Lys residues are marked with a purple * and lid sequence is delimited by a purple rectangle (model generated in http: / / sable.cchmc.org/, accessed on 23 October 2021) [35]. (B) LipMATCCR11 Lid domain generated with MODELLER v1.11 tool [36]; Lys 182 and Lys 226 participate in the lid opening.

LipMatCCR11 lipase crude extract was obtained as the supernatant after the centrifugation of a sonicated fresh culture of the recombinant E. coli-pET-3b-LipMatCCR11 as explained in Section 3.1. Prior to its use for each treatment, the enzymatic crude extract was characterized with respect to its protein content and lipolytic activity. The protein concentration in the crude extract was $28 \pm 2 \mathrm{mg} / \mathrm{mL}$, and the volumetric lipolytic activity was $2547 \pm 133 \mathrm{U} / \mathrm{mL}$ with a specific activity of $91 \pm 4 \mathrm{U} / \mathrm{mg}$.

Stepwise regression allowed the identification of the response equation, where each $x_{j}(j=1, \ldots, 5)$ represented the coded factor level (Equation (1)). This model demonstrated an excellent reproduction of the experimental behavior by having a coefficient of determination higher than 0.95 , which indicated that no more than $5 \%$ of the total variance in the data could not be explained by the regression (Figure 2). According to this model, glutaraldehyde concentration $(\times 4)$ was the variable showing the highest influence (negative) on CLEA activity, while the effect of the other factors was similar. In this case, higher CLEA activities were associated with increasing protein concentration $(\times 1)$ and $\mathrm{pH}$ levels $(\times 3)$, while precipitation agent $(\times 2)$ and temperature $(\times 5)$ had the reverse effect.

$$
\ln y=5.72+0.54 x_{1}-0.62 x_{2}+0.51 x_{3}-2.44 x_{4}-0.69 x_{5}\left(R^{2}=0.95\right)
$$

Significant variables were analyzed using the path of steepest ascent; however, no further increase in the response variable beyond the maximum obtained during the experimental development of the design was observed. Therefore, the characterization was performed using the combination of studied variables corresponding to treatment 8 , which were: a protein concentration of $3.25 \mathrm{mg} / \mathrm{mL}, 40 \%\left(\mathrm{NH}_{4}\right)_{2} \mathrm{SO}_{4}$ as the precipitant agent, $\mathrm{pH} 9$, glutaraldehyde $40 \mathrm{mM}$ as the cross-linker agent, reaction temperature of $20^{\circ} \mathrm{C}$, for $7.5 \mathrm{~h}$.

The mass activity for the LipMatCCR11-CLEAs was $7750 \mathrm{U} / \mathrm{g}$, and the amount of protein immobilized was $520 \mathrm{mg}$ of protein/g. An important decrease in lipolytic activity was observed ( $85 \%$, in comparison with soluble enzyme), which could be related to a change in the enzyme conformation during immobilization, and/or to an insufficient rigidity of the enzyme. The interference of the host's proteins with the immobilization processes could be another factor affecting enzymatic activity. Nevertheless, the improvement in thermostability and the capacity for reuse (see below) give LipMatCCR11-CLEAs added value $[17,40]$. 


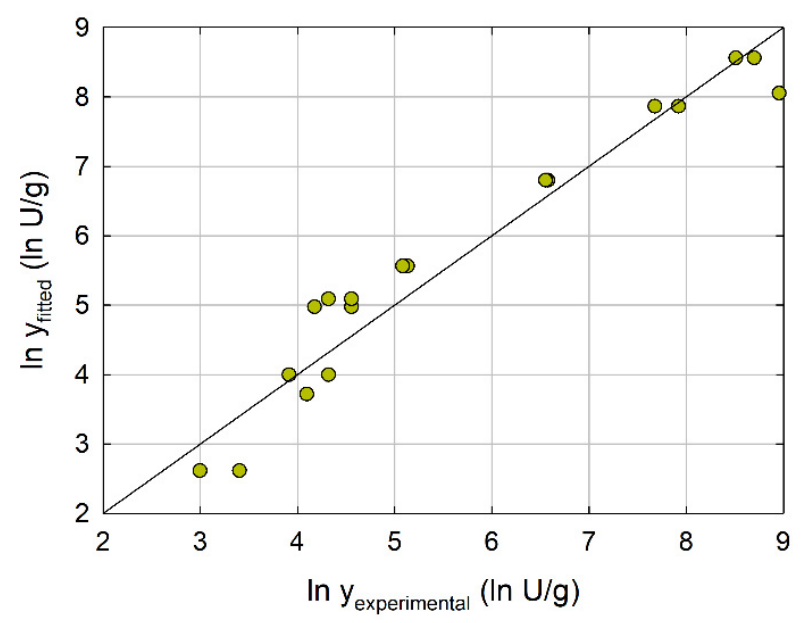

Figure 2. Linear regression of the model obtained in optimization of LipMatCCR11-CLEA production.

\subsection{Biochemical Characterization}

2.2.1. Effect of Temperature and $\mathrm{pH}$ on LipMatCCR11-CLEA Activity

The effect of temperature and $\mathrm{pH}$ on the hydrolytic activity of soluble enzyme and LipMatCCR11-CLEAs is depicted in Figure 3A. The optimal temperature was recorded at $40{ }^{\circ} \mathrm{C}$ for both the soluble enzyme and the CLEAs.
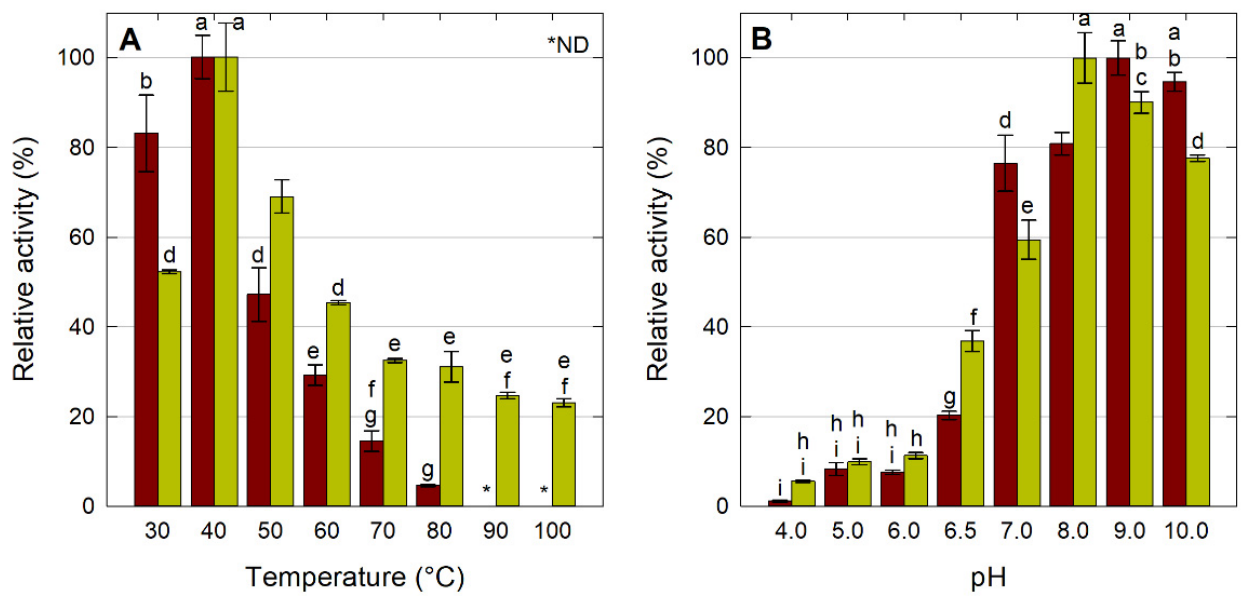

Figure 3. Characterization of LipMatCCR11-CLEAs. Effect of temperature (A) and pH (B) on lipolytic activity. All values are the mean of three replicates. Red: LipMatCCR11, Green: LipMatCCR11CLEAs Error bars represent the standard deviation within the data set. Different lowercase letters indicate significant differences according to Tukey's multiple comparison tests $(p<0.05)$. The $100 \%$ value corresponds to a CLEA activity of $7755 \pm 144 \mathrm{U} / \mathrm{g}$. *: Non-detectable.

It was found that while a sharp decrease in activity was observed in the soluble enzyme at temperatures above $70{ }^{\circ} \mathrm{C}$, more than $20 \%$ of the activity of LipMatCCR11CLEAs was conserved at over $100{ }^{\circ} \mathrm{C}$; this phenomenon has been observed with CLEAs for other enzymes, and it is attributed to a decrease in the conformational flexibility of the enzyme associated with the formation of covalent bonds within the aggregates $[28,29,38]$.

The effect of $\mathrm{pH}$ on the hydrolytic activity was studied at $\mathrm{pH} 4-10$ at $40{ }^{\circ} \mathrm{C}$; higher $\mathrm{pH}$ values were not assessed due to the non-enzymatic hydrolysis of the substrate ( $p$-nitrophenyl-laurate). The activity profiles obtained are represented in Figure 3B. The optimal $\mathrm{pH}$ values for the soluble and immobilized enzyme were 9 and 8 , respectively. There are reports in the literature of similar variations in the optimal $\mathrm{pH}$ between soluble and immobilized enzymes by this method; although the CLEA formation process does not involve the use of any support, previous studies have reported changes in the optimal $\mathrm{pH}$ 
of different hydrolases that can tend towards alkalinity [22,29] or acidity [24,31]. Regarding the change to more acidic $\mathrm{pH}$ values, Mahmod et al. [24] observed a change in the optimal $\mathrm{pH}$ value of the free enzyme from 8 to 6.8 when the CLEAs were synthesized with the Ictalurus punctatus protease.

Figure $4 \mathrm{~A}$ shows the results from the thermostability assay; the soluble enzyme lost more than $70 \%$ of its activity after $1 \mathrm{~h}$ at $30{ }^{\circ} \mathrm{C}$ and only conserved $1 \%$ of its activity at $60{ }^{\circ} \mathrm{C}$, while the LipMatCCR11-CLEAs conserved more than $30 \%$ of their residual activity under the same conditions. Similarly, increases in the thermostability of CLEAs have been reported for Rhizopus orizae lipase, whose cross-linked derivatives retained $50 \%$ of their activity after incubation at $60^{\circ} \mathrm{C}$, in contrast to its free form in which activity was completely lost after being incubated for $15 \mathrm{~min}$ at the same temperature [29].
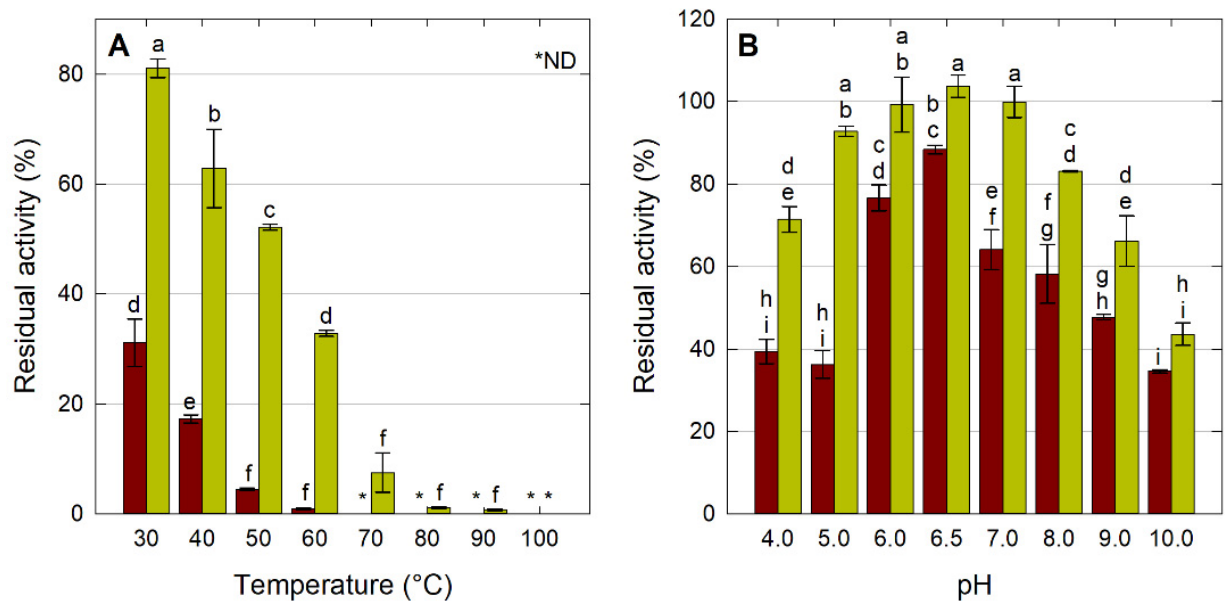

Figure 4. Characterization of LipMatCCR11-CLEAs. Effect of temperature (A) and pH (B) on lipolytic stability. All values are the mean of three replicates. Red: LipMatCCR1, Green: LipMatCCR11-CLEAs. Error bars represent the standard deviation within the data set. Different lowercase letters indicate significant differences according to Tukey's multiple comparison tests $(p<0.05)$. The $100 \%$ value corresponds to a CLEA activity of $7755 \pm 144 \mathrm{U} / \mathrm{g}$. *: Non-detectable.

The effect of $\mathrm{pH}$ on the stability of the soluble LipMatCCR11 and LipMatCCR11CLEAs was evaluated by quantifying the residual activity after incubating the enzyme preparations for $24 \mathrm{~h}$ at room temperature in buffers of $\mathrm{pH} 4-10$. The percentages of residual activity of the soluble and immobilized lipase are presented in Figure 4B. The LipMatCCR11-CLEAs exhibited a stability that was significantly higher (10-50\%) than the soluble enzyme in the evaluated $\mathrm{pH}$ range. The increase in stability at different $\mathrm{pHs}$ for immobilized hydrolases has been previously described, and it has been attributed to the protection that the crosslinked network provides to the reacting groups of the enzyme structure [23]. The fact that $\mathrm{pH}$ resistance was lower at optimum $\mathrm{pH}$ in comparison with neutral $\mathrm{pHs}$ could be due to changes in the protonation state of some functional groups as a result of the prolonged exposure of the enzyme to the alkaline environment [41].

\subsubsection{Effect of Metal Ions on LipMatCCR11-CLEA Activity}

The residual activity of the soluble lipase and the LipMatCCR1-CLEAs after their incubation in solutions of different inorganic chlorides is depicted in Figure 5A. As can be seen, there were no significant differences $(p<0.05)$ in the lipolytic activity of CLEAs and soluble lipase due to exposure to metal ions except for $\mathrm{Ca}^{+2}, \mathrm{Cu}^{+2}$, and $\mathrm{Hg}^{+1}$; exposure to $\mathrm{Ca}^{+2}$ provoked a significant activation $(120 \%)$ in LipMatCCR11-CLEA activity that could be due to the promotion of conformational changes of the enzyme in domains associated with thermostability [31]. The increase in lipolytic activity after incubation in the presence of some divalent cations has been reported for lipases and esterases from Bacillus and Geobacillus [42-44]. $\mathrm{Cu}^{+2}$ and $\mathrm{Hg}^{+1}$ provoked an inhibitory effect of 80 and 
$95 \%$, respectively, on both forms of the enzyme. A similar effect has been reported for other thermophilic lipases and esterases $[43,45]$, and although its exact role in the inactivation of lipases has not been clarified, this phenomenon could be due to the induction of a structural disturbance in the protein, probably due to the association with residues that participate in the catalytic processes [46].
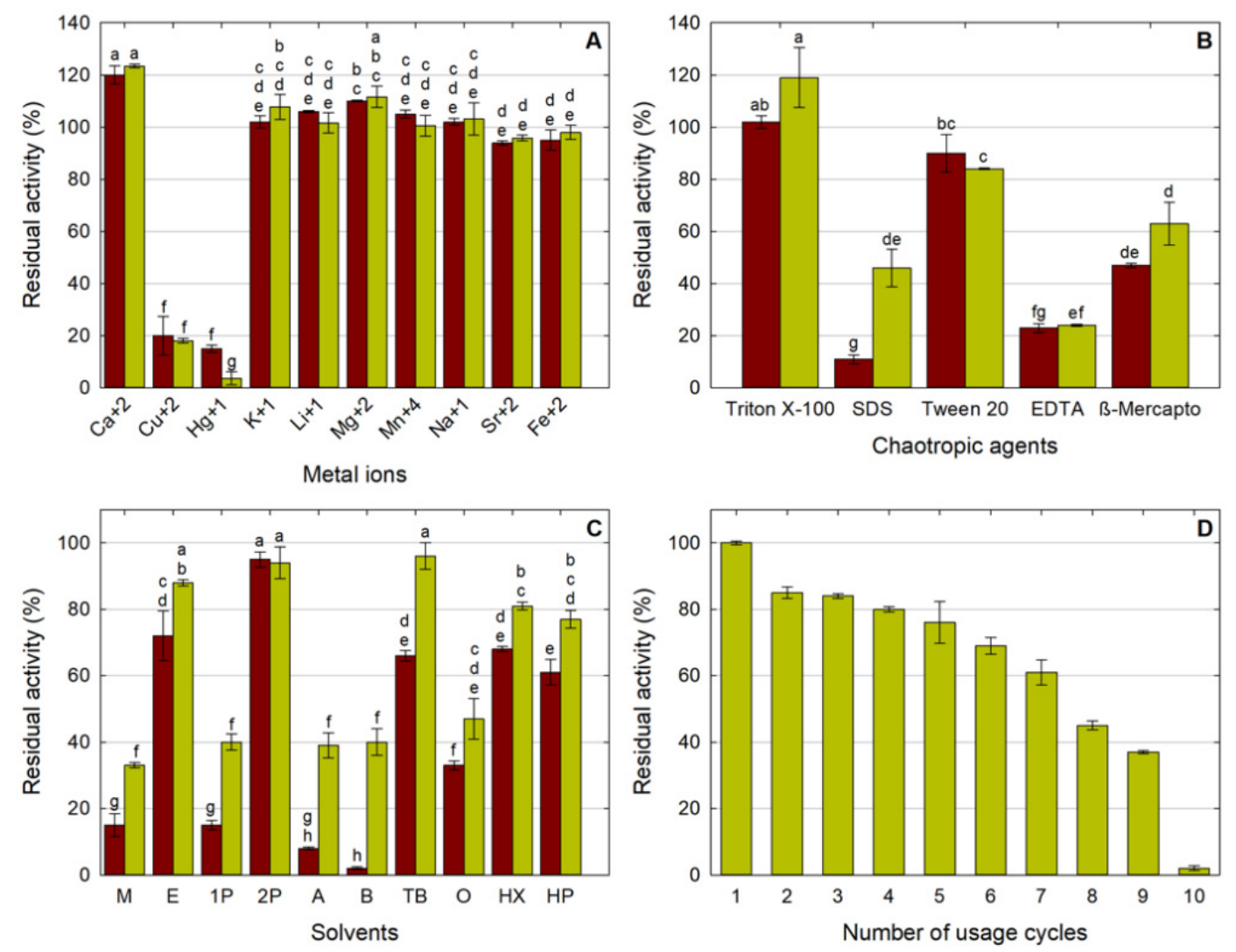

Figure 5. Characterization of LipMatCCR11-CLEAs. (A) Stability against metal ions; (B) stability on chaotropic agents; (C) stability on solvents M: methanol, E: ethanol, 1P: 1-propanol, 2P: 2-propanol, A: acetone, B: butanol, TB: tert-butanol, O: octanol, HX: hexane, HP: heptane. (D) Reusability of LipMAtCCR11-CLEAs. All values are the mean of three replicates Red: LipMatCCR1, Green: LipMatCCR11-CLEAs. Error bars represent the standard deviation within the data set. Different lowercase letters indicate significant differences according to Tukey's multiple comparison tests $(p<0.05)$. The 100\% value corresponds to a CLEA activity of $7755 \pm 144 \mathrm{U} / \mathrm{g}$.

\subsubsection{Stability in Chaotropic Agents}

As depicted in Figure 5B, there were no significant differences between the activities of LipMatCCR11-CLEAs and their soluble counterparts in the presence of Triton X-100, Tween 20 , and $\beta$-mercaptoethanol $(p<0.05)$. In contrast, sodium dodecyl sulfate (SDS) provoked a $90 \%$ decrease in the activity of the soluble enzyme, while LipMatCCR11-CLEAs retained more than $40 \%$ of their residual activity under the same conditions. A similar behavior was reported for the bran grain lipase after its immobilization by entrapment in alginate beads, which presented a $50 \%$ increase in its resistance to SDS-mediated inactivation [47]. Nonionic surfactants such as Triton X-100 or Tween ${ }^{\circledR}$ series compounds are considered "softer" than their charged counterparts, and usually have an activating effect on lipases because they can emulate the chemical environment favorable to triggering the active catalytic conformation [48]. As observed in the lipase obtained from Geobacillus sp. EPT9 [49], Tween ${ }^{\circledR} 20$ caused a moderate inhibition of LipMatCCR11 in its two forms. Reducing agents such as $\beta$-mercaptoethanol mainly affect the cysteine residues that form disulfide bridges; LipMatCCR11 lipase contains only two cysteine residues in its sequence, and the moderate inactivation caused by $\beta$-mercaptoethanol for both forms of the enzyme suggests 
that these residues are not a part of catalytic site stabilization. After treatment with EDTA, LipMatCCR11-CLEAs lost more than $70 \%$ of their initial activity, so it can be inferred that the cross-linking was not able to fix the active conformation induced by the presence of cations usually associated with stability, such as $\mathrm{Ca}^{+2}[50]$.

\subsubsection{Stability in Organic Solvents}

Stability in organic solvents was evaluated using 10 solvents with different log P. The residual activity after each treatment is depicted in Figure 5C. In general, LipMatCCR11CLEAs were significantly $(p<0.05)$ more stable than the soluble lipase in the presence of all the solvents studied; the immobilized variety retained 2 to 20 times more activity than the soluble enzyme in polar solvents such as methanol, 1-propanol, acetone, and n-butanol. Despite the resistance of lipases to the effect of hydrophobic organic solvents [51], the behavior that these enzymes show against solvents considered polar $(\log p<2.0)$ is usually variable [52].

Although there has been an increase in the implementation of green chemistry-based protocols, the use of polar solvents continues as part of the reaction medium or as building blocks; the use of short-chain alcohols to produce biodiesel is an example of both applications [53]. Detailed experiments regarding the effect of different organic solvents on the catalytic activity of CLEAs have shown that the cross-linking process increases the stability against polar compounds, especially against short-chain alcohols. This high stability can be attributed to the fact that the immobilized enzyme structure is stabilized by cross-linking and manages to maintain its catalytic activity even after the removal of the solvation layer from the enzyme surface caused by solvents $[54,55]$.

\subsubsection{Reusability of Immobilized Lipase Test}

For any industrial application, the possibility of reusing the enzymes is of vital importance to the goal of reducing total production costs $[53,56]$. As can be seen in Figure 5D, after being subjected to nine cycles under experimental conditions, LipMatCCR11-CLEAs retained $37 \%$ of their initial activity and reached total inactivation after 10 cycles. A similar reusability was reported by Jamwal et al. [57] for the cross-linked aggregates of the thermostable lipase from Geobacillus sp. CLEA reuse capacity may vary due to multiple factors such as the nature of the enzyme used, the production process, or the test conditions; the loss of activity during reuse might be due to changes in CLEA morphology as a result of mechanical agitation, or to the leaching of the enzymes into the reaction medium $[23,30,31,39]$.

\subsubsection{Storage Stability of LipMatCCR1-CLEAs}

Storage at $4{ }^{\circ} \mathrm{C}$ and $25^{\circ} \mathrm{C}$ for 30 days did not exert a significant effect on the activity of the LipMatCCR11-CLEAs $(p<0.05)$. These results agree with the experiments conducted by Yang et al. [58], in which CLEAs of Thermomyces lanuginosus lipase did not show any significant decrease in activity after 20 days of storage at $4{ }^{\circ} \mathrm{C}$. Other CLEAs have been reported with outstanding storage stability, such as the common mushroom tyrosinase CLEAs stored at $4{ }^{\circ} \mathrm{C}$ and $25^{\circ} \mathrm{C}$ for 3 months, retaining 84 and $83 \%$ of their activity, respectively [28].

\subsubsection{Morphological Analysis}

The morphology and size of the LipMatCCR11-CLEAs and the lyophilized soluble protein were determined by scanning electron microscopy. In the lyophilized sample, large lamellar structures of irregular shape were observed (Figure 6), similar to what was observed in reported micrographs of other protein lyophilizates, which in general can be attributed to the fragile nature of the resulting solid [59]. 


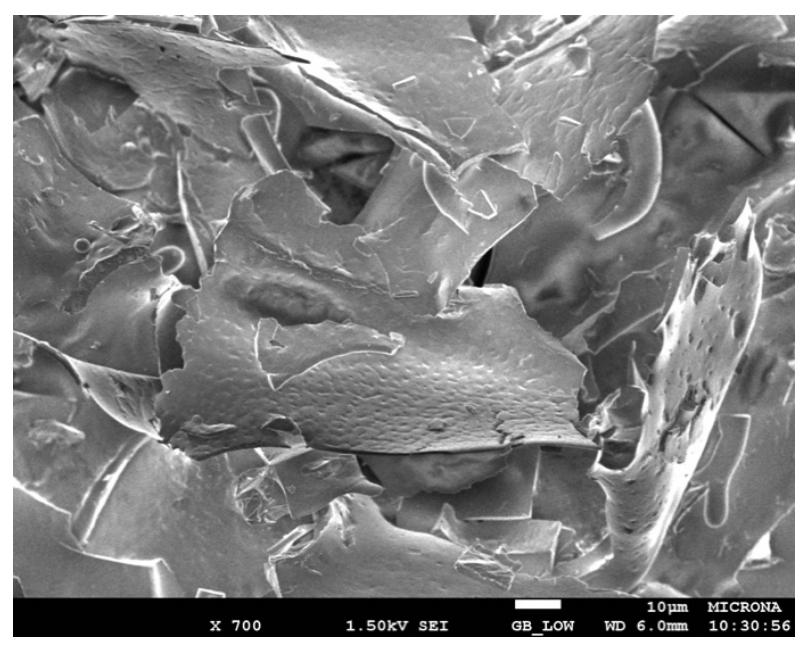

Figure 6. SEM Image of LipMatCCR11 in lyophilized form. Magnification 700×.

Regarding the morphology of the LipMatCCR11-CLEAs, Figure 7 shows individual aggregates of approximately $0.25 \mu \mathrm{m}$ in diameter that form clusters or branched aggregates with sizes ranging from 10 to $100 \mu \mathrm{m}$. This places them in the group of type 2 CLEAs (associated aggregates in large groups with individual sizes of less than $1 \mu \mathrm{m}$ ). The formation of branched aggregates could be the consequence of covalent bond formations between the reactive groups on the surfaces of the individual aggregates.
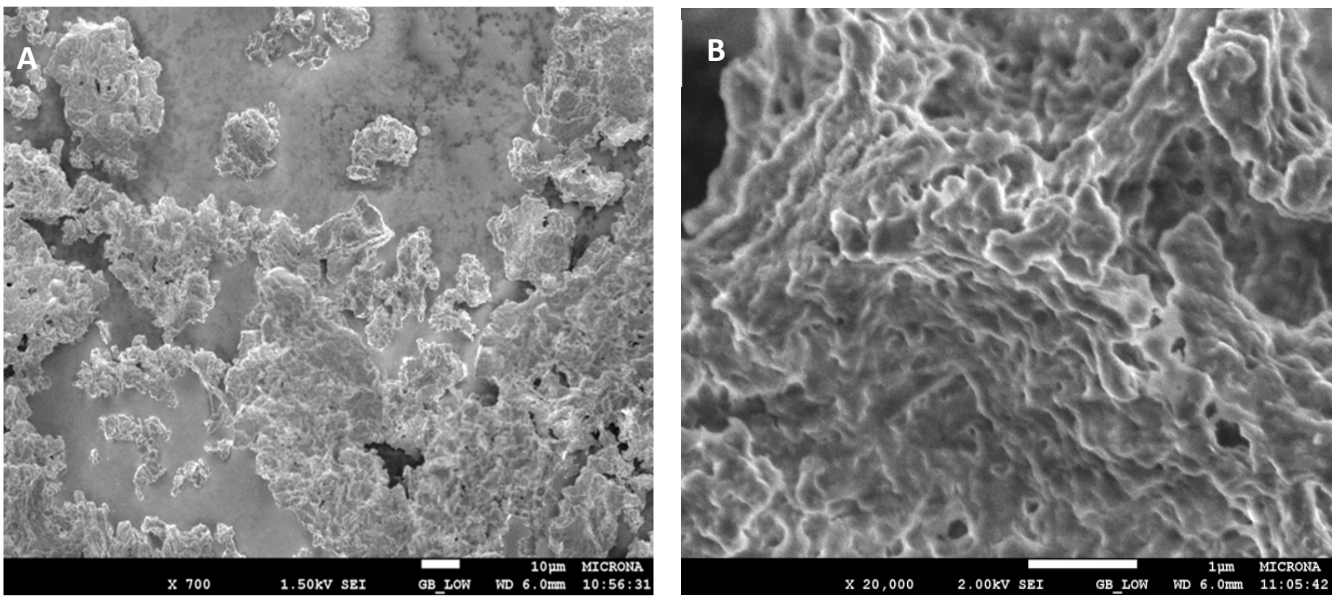

Figure 7. SEM Image of LipMatCCR11-CLEAs. (A) Magnification: 700×. (B) Magnification: 20,000× .

\section{Materials and Methods}

Reagents, solvents, and culture media were of reagent grade, used without any additional purification, and they were obtained from Sigma-Aldrich Química, Toluca, México. To produce the lipase, E. coli BL21 (DE3) transformed with the plasmid pET-3bLipMatCCR11 was used (E. coli BL 21 (DE3) was purchased from New England Biolabs, Ipswich, MA, USA; plasmid was purchased from Merck, Darmstadt, Germany) [34].

\subsection{Production and Recovery of the LipMatCCR11 Lipase}

LipMatCCR11 lipase was obtained from a fresh culture of the recombinant E. coli-pET3b-LipMatCCR11 as described by Badillo-Zeferino et al. [34] as follows: After centrifugation cells were placed on ice and suspended in $0.1 \mathrm{M}$ potassium phosphate buffer ( $\mathrm{pH}$ 9). With the aid of an ultrasonic processor (Cole Palmer Ultrasonic Processor Mod. GB 130PB, Court Vernon Hills, IL, USA) cells were disrupted with ten $15 \mathrm{~s}$ pulses (total applied energy: $2500 \mathrm{~J}$ ) separated by a $30 \mathrm{~s}$ pause, at a $20 \mathrm{kHz}$ frequency and high amplitude 
(60\%). Lipolytic activity and protein concentration were measured in the supernatant after centrifuging at $14,000 \times g$ at $4{ }^{\circ} \mathrm{C}$ for $15 \mathrm{~min}$.

\subsection{Lipolytic Activity and Protein Concentration}

Lipolytic activity of both soluble and immobilized enzymes was determined by a spectrophotometric method: $5 \mathrm{mg}$ of CLEA lipase or $100 \mu \mathrm{L}$ of the diluted crude enzyme were incubated in $0.05 \mathrm{M}$ phosphate buffer ( $\mathrm{pH} 6.5 ; 0.9 \mathrm{~mL}$ final volume), and $0.1 \mathrm{~mL}$ of $10 \mathrm{mM} p$-nitrophenyl-laurate in ethanol for $30 \mathrm{~min}$ at $60^{\circ} \mathrm{C}$. Reaction was stopped with $250 \mathrm{~mL}$ of $\mathrm{Na}_{2} \mathrm{CO}_{3}$ and centrifugation at $16,000 \times \mathrm{g}$ at $4{ }^{\circ} \mathrm{C}$ for $10 \mathrm{~min}$, after which aliquots of the supernatants were taken and their absorbance at $405 \mathrm{~nm}$ measured in a Stat Fax ${ }^{\circledR}$ 2100 microplate reader (Awareness Technologies, Bellport, NY, USA) [60]. The protein concentration was evaluated by the Lowry method [61].

\subsection{Synthesis of the LipMatCCR11-CLEAs}

E. coli-pET-3b-LipMatCCR11 was lysed and diluted with buffers of various $\mathrm{pHs}$ (6.5-9) in order to adjust the desired concentration of protein, as reported by López-Serrano et al. [62] Then, Triton X-100 was added up to $0.15 \% v / v$; next, ammonium sulfate was added up to each percentage (20-60) of final saturation. Immediately afterwards, the cross-linking process started with the addition of $25 \%$ aqueous glutaraldehyde solution. The reaction was allowed to continue under isothermal conditions at each selected temperature $\left(4-25^{\circ} \mathrm{C}\right)$, and once the time of each treatment was completed (2-24 h), reaction was stopped by adding buffer with the corresponding $\mathrm{pH}$ to dilute the saturation of ammonium sulfate below $15 \%$ in the reaction mixture. The LipMatCCR11-CLEAs were washed three times with the corresponding $\mathrm{pH}$ buffer in a buffer-CLEA ratio of 10:1, recovered by centrifugation at $9000 \times g, 15 \mathrm{~min}, 4^{\circ} \mathrm{C}$, and dried in a Speed Vacuum Concentrator Thermo Fisher Scientific ${ }^{\circledR}$ (Asheville, NC, USA). CLEAs were stored at $4{ }^{\circ} \mathrm{C}$.

\subsection{Optimization of LipMatCCR11-CLEA Production}

Six factors were selected in this study to investigate the production of the LipMatCCR11CLEAs: (1) protein concentration $(\times 1, \mathrm{mg}$ protein $/ \mathrm{mL}),(2)$ precipitation agent $(\times 2$, ammonium sulfate, \% sat), (3) $\mathrm{pH}(\times 3)$, (4) glutaraldehyde concentration $(\times 4, \mathrm{mM}),(5)$ temperature $\left({ }^{\circ} \mathrm{C}\right)$, and $(6)$ incubation time. Each factor was evaluated at five levels (Table 1 ) according to a uniform design to better characterize the experimental region with a minimum number of experiments [63]. The selected $U_{10}\left(5^{6}\right)$ uniform design (10 treatments with 6 factors at 5 levels) is presented in Table 2. Each treatment was carried out in duplicate.

Stepwise regression was applied to choose the predictive variables in the response equations. Besides only including significant terms, the final model was selected to have the highest $R^{2}$ value and the lowest PRESS statistic. Linear regression (based on ordinary least squares), analysis of variance, and numerical procedures were performed with the Matlab software and its Statistic Toolbox 7.3 (Matlab R2010a, MathWorks Inc., Natick, MA, USA).

\subsection{Characterization of the LipMatCCR11-CLEAs}

\subsubsection{Effect of $\mathrm{pH}$ and Temperature on Lipase Activity}

The optimum $\mathrm{pH}$ and temperature were determined by measuring the hydrolytic activity of soluble and immobilized enzymes in a pH range of $4-10$ at $40^{\circ} \mathrm{C}$, and a temperature range of $30-100{ }^{\circ} \mathrm{C}$, at $\mathrm{pH}$ of 6.5 . The tests were carried out with $100 \mu \mathrm{L}$ of enzymatic extract diluted in the corresponding buffer, or with $0.005 \mathrm{~g}$ of LipMatCCR11-CLEAs. Lipolytic activity was expressed as relative activity (\%) [64].

\subsubsection{Effect of $\mathrm{pH}$ and Temperature on Enzyme Stability}

Samples of both soluble and immobilized enzymes were incubated at different temperatures $\left(30-100{ }^{\circ} \mathrm{C}\right)$ for $1 \mathrm{~h}$. The residual activities were determined as described above. To determine the stability against exposure to different $\mathrm{pH}$ conditions, aliquots of $100 \mu \mathrm{L}$ of enzymatic extract ( $5 \mathrm{mg}$ protein/mL) and LipMatCCR11-CLEAs (approximately $0.050 \mathrm{~g}$ ) 
were incubated for $24 \mathrm{~h}$ at $25{ }^{\circ} \mathrm{C}$ in $1 \mathrm{~mL}$ of buffer solution $(50 \mathrm{mM})$ of different pHs: (4.0, 5.0, 6.0, 6.5, 7.0, 8.0, 9.0, and 10.0). After incubation, LipMatCCR11-CLEAs were removed by filtration and dried under vacuum; subsequently, residual lipolytic activity was determined under the conditions previously indicated at $40^{\circ} \mathrm{C}$. Results were expressed as residual activity (\%).

Table 1. Factor and levels for investigating the production of the LipMatCCR11-CLEAs.

\begin{tabular}{|c|c|c|c|c|c|c|}
\hline \multirow{2}{*}{ Factor } & \multirow{2}{*}{ Code } & \multicolumn{5}{|c|}{ Levels* } \\
\hline & & $1(-1)$ & $2(-1 / 2)$ & $3(0)$ & $4(1 / 2)$ & $5(1)$ \\
\hline Protein concentration $(\mathrm{mg} / \mathrm{mL})$ & $x_{1}$ & 1 & 3.25 & 5.5 & 7.75 & 10 \\
\hline Ammonium sulfate (\% sat) & $x_{2}$ & 20 & 30 & 40 & 50 & 60 \\
\hline $\mathrm{pH}$ & $x_{3}$ & 6.5 & 7.125 & 7.75 & 8.375 & 9 \\
\hline Glutaraldehyde (mM) & $x_{4}$ & 40 & 105 & 170 & 235 & 300 \\
\hline Temperature $\left({ }^{\circ} \mathrm{C}\right)$ & $x_{5}$ & 4 & 9.25 & 14.5 & 19.75 & 25 \\
\hline Incubation time (h) & $x_{6}$ & 2 & 7.5 & 13 & 18.5 & 24 \\
\hline
\end{tabular}

${ }^{*}$ Numbers in parentheses represent the coded levels used in the regression analysis.

Table 2. Production of the LipMatCCR11-CLEAs according to uniform design $U_{10}\left(5^{6}\right)$.

\begin{tabular}{|c|c|c|c|c|c|c|c|}
\hline Treatment & $x_{1}$ & $x_{2}$ & $x_{3}$ & $x_{4}$ & $x_{5}$ & $x_{6}$ & $y(\mathrm{U} / \mathrm{g}) *$ \\
\hline 1 & 4 & 4 & 5 & 4 & 3 & 5 & $80 \pm 22^{e}$ \\
\hline 2 & 3 & 2 & 2 & 1 & 2 & 5 & $5485 \pm 626^{b}$ \\
\hline 3 & 5 & 4 & 3 & 2 & 1 & 1 & $2458 \pm 344^{c}$ \\
\hline 4 & 1 & 5 & 3 & 2 & 5 & 4 & $85 \pm 31^{\mathrm{e}}$ \\
\hline 5 & 5 & 1 & 4 & 3 & 4 & 4 & $710 \pm 12^{d}$ \\
\hline 6 & 2 & 1 & 1 & 3 & 3 & 1 & $165 \pm 6^{\text {de }}$ \\
\hline 7 & 3 & 5 & 1 & 4 & 2 & 3 & $60 \pm 0^{e}$ \\
\hline 8 & 2 & 3 & 5 & 1 & 4 & 2 & $7755 \pm 144^{a}$ \\
\hline 9 & 1 & 2 & 4 & 5 & 1 & 3 & $63 \pm 15^{\mathrm{e}}$ \\
\hline 10 & 4 & 3 & 2 & 5 & 5 & 2 & $25 \pm 6^{\mathrm{e}}$ \\
\hline
\end{tabular}

* Values followed by a different letter are statistically different (Tukey's test, $p<0.05$ ).

\subsubsection{Effect of Metallic Ions and Chaotropic Agents on Enzyme Stability}

In order to assess the effect of metal ions on the activity of soluble and LipMatCCR1CLEAs, aliquots of $100 \mu \mathrm{L}$ of enzyme extract $(5 \mathrm{mg}$ protein $/ \mathrm{mL}$ ) or $0.010 \mathrm{~g}$ of LipMatCCR11CLEAs were incubated in a $1 \mathrm{mM}$ aqueous solution of $\mathrm{CaCl}_{2}, \mathrm{KCl}, \mathrm{MgCl}_{2}, \mathrm{NaCl}, \mathrm{HgCl}, \mathrm{LiCl}$, $\mathrm{FeCl}_{2}, \mathrm{MgCl}_{2}, \mathrm{SrCl}_{2}$, and $\mathrm{CuCl}_{2}$, and in solutions of detergents and chaotropic agents, all of them dissolved in $50 \mathrm{mM}$ sodium phosphate buffer, $\mathrm{pH}$ 6.5. The compounds analyzed were the following: EDTA (1 mM), $\beta$-mercaptoethanol 1\% $(v / v)$, Triton X-100 1\% $(v / v)$, Tween ${ }^{\circledR} 201 \%(v / v)$, and dodecyl sulfate of sodium (SDS) $0.1 \%(w / v)$. The incubation was carried out for $1 \mathrm{~h}$ at $30^{\circ} \mathrm{C}$. At the end of incubation time, lipolytic activity was determined according to the standard conditions previously indicated, at $40^{\circ} \mathrm{C}$. Lipolytic activity was expressed as residual activity (\%).

\subsubsection{Effect of Organic Solvents on Lipase Activity}

To determine the stability of LipMatCCR11-CLEAs in organic solvents, samples of $0.010 \mathrm{~g}$ of LipMatCCR11-CLEAs and aliquots of $100 \mu \mathrm{L}$ of enzyme extract $(5 \mathrm{mg}$ protein $/ \mathrm{mL}$ ) were incubated for $30 \mathrm{~min}$ in $500 \mu \mathrm{L}$ of different organic solvents (methanol, ethanol, acetone, 1-propanol, 2-propanol, butanol, tert-butanol, hexane, heptane, oc- 
tanol). Subsequently, the lipolytic activity of the samples was determined according to the standard conditions previously indicated, at $40^{\circ} \mathrm{C}$. Lipolytic activity was expressed as residual activity.

\subsubsection{Reutilization of LipMatCCR11-CLEAs}

The study of the stability of LipMatCCR11-CLEAs for reuse was carried out as follows: the initial lipolytic activity was determined as previously indicated, and once the first cycle of activity was concluded, the LipMatCCR11-CLEAs were washed three times with $50 \mathrm{mM}$ sodium phosphate buffer, $\mathrm{pH} 6.5$, recovered by filtration, and dried under vacuum at room temperature. Once dry, the procedure was repeated until the lipolytic activity approached zero. The residual lipolytic activity was expressed as a percentage.

\subsection{Microstructural Analysis}

The morphology and size of LipMatCCR11-CLEAs and the soluble protein in lyophilized form were determined by electron scanning micrographs using a JEOL scanning electron microscope (SEM) model JSM-7600F (JEOL, Tokyo, Japan) located at the Center for Research in Micro and Nanotechnology (MICRONA) (Universidad Veracruzana). Prior to their observation, the LipMatCCR11-CLEAs and the lyophilized enzyme were stored in a vacuum desiccator; the micrographs of both samples were made without any additional coating with an operating voltage between 1.0 and $2.0 \mathrm{keV}$ in Gentle Beam mode.

\section{Conclusions}

The immobilization of the recombinant thermoalkaliphilic lipase LipMatCCR11 in the form of cross-linked aggregates (CLEAs) allowed us to obtain a robust biocatalyst in solid form, free of support, with greater thermostability, and reusable and resistant to storage.

The statistical approach utilized in this work was not sufficient to maximize the lipolytic activity of the CLEAs. To improve the stability and catalytic capacity of LipMatCCR11CLEAs, it would be necessary to investigate the structural changes occurring in the protein during the immobilization process. These studies will be undertaken in the near future. To the best of our knowledge, this is the first report that describes the production of crosslinked aggregates of a thermoalkaliphilic lipase, their biochemical characterization, and the assessment of their reutilization capacity and storage resistance.

Author Contributions: Conceptualization, M.-G.S.-O., R.-M.O.-R., G.-L.B.-Z. and A.K.N.; methodology, G.-L.B.-Z., M.-G.S.-O. and R.Q.-C.; software, I.-I.R.-L. and J.-G.D.-C.; validation, M.-G.S.-O., I.-I.R.-L., A.A.-A. and A.K.N.; formal analysis, I.-I.R.-L. and M.-G.S.-O.; investigation, G.-L.B.-Z., R.-M.O.-R. and M.-G.S.-O.; resources, R.-M.O.-R., A.A.-A., A.K.N. and D.D.N.; data curation, I.-I.R.-L., R.-M.O.-R., M.-G.S.-O., J.-G.D.-C. and G.-L.B.-Z.; writing-original draft preparation, R.-M.O.-R., G.-L.B.-Z., I.-I.R.-L. and M.-G.S.-O.; writing—review and editing, M.-G.S.-O., R.-M.O.-R., A.A.-A., A.A.K., D.D.N. and A.K.N.; visualization, I.-I.R.-L.; supervision, R.-M.O.-R. and M.-G.S.-O.; project administration, R.-M.O.-R. and M.-G.S.-O. All authors have read and agreed to the published version of the manuscript.

Funding: This work was funded by the Researchers Supporting Project Number (RSP-2021/339) King Saud University, Riyadh, Saudi Arabia.

Institutional Review Board Statement: Not applicable.

Informed Consent Statement: Not applicable.

Data Availability Statement: Not applicable.

Conflicts of Interest: The authors declare no conflict of interest.

Sample Availability: Samples of the compounds are not available from the authors. 


\section{References}

1. Guncheva, M.; Zhiryakova, D. Catalytic properties and potential applications of Bacillus lipases. J. Mol. Catal. B Enzym 2011, 68, 1-21. [CrossRef]

2. Kapoor, M.; Gupta, M.N. Lipase promiscuity and its biochemical applications. Proc. Biochem. 2012, 47, 555-569. [CrossRef]

3. Sánchez-Otero, M.G.; Quintana-Castro, R.; Mora-González, P.C.; Márquez-Molina, O.; Valerio-Alfaro, G.; Oliart-Ros, R.M. Enzymatic reactions and synthesis of n-butyl caproate: Esterification, transesterification and aminolysis using a recombinant lipase from Geobacillus thermoleovorans CCR11. Environ. Technol. 2010, 10, 1101-1106. [CrossRef]

4. Kumar, A.; Park, G.D.; Patel, S.K.S.; Kondaveeti, S.; Otari, S.; Anwar, M.Z.; Kalia, V.C.; Singh, Y.; Kim, S.C.; Cho, B.K.; et al. SiO 2 microparticles with carbon nanotube derived mesopores as an efficient support for enzyme immobilization. Chem. Eng. J. 2019, 359, 1252-1264. [CrossRef]

5. Treichel, H.; de Oliveira, D.; Mazutti, M.A.; Di Luccio, M.; Oliveira, J.V. A Review on Microbial Lipases Production. Food Bioprocess Technol. 2010, 3, 182-196. [CrossRef]

6. Carrasco-López, C.; Godoy, C.; de Las Rivas, B.; Fernández-Lorente, G.; Palomo, J.M.; Guisán, J.M.; Fernández-Lafuente, R.; Martínez-Ripoll, M.; Hermoso, J.A. Activation of bacterial thermo alkalophilic lipases is spurred by dramatic structural rearrangements. J. Biol. Chem. 2009, 284, 4365-4372. [CrossRef]

7. Skjold-Jorgensen, J.; Vind, J.; Moroz, O.V.; Blagova, E.; Bhatia, V.K.; Svendsen, A.; Wilson, K.S.; Bjerrum, M.J. Controlled lid-opening in Thermomyces lanuginosus lipase-An engineered switch for studying lipase function. Biochim. Biophys. Acta 2017, 1865, 20-27. [CrossRef] [PubMed]

8. Almeida, R.V.; Branco, R.V.; Peixoto, B.; da Silva, L.C.; Alqueres, S.M.C.; Freire, D.M.G. Immobilization of a recombinant thermostable esterase (Pf2001) from Pyrococcus furiosus on microporous polypropylene: Isotherms, hyperactivation and purification. Biochem. Eng. J. 2008, 39, 531-537. [CrossRef]

9. Fernández-Lorente, G.; Cabrera, Z.; Godoy, C.; Fernández-Lafuente, R.; Palomo, J.M.; Guisán, J.M. Interfacially activated lipases against hydrophobic supports: Effect of the support nature on the biocatalytic properties. Proc. Biochem. 2008, 43, $1061-1067$. [CrossRef]

10. Timucin, E.; Sezerman, O.U. The Conserved Lid Tryptophan, W211, Potentiates Thermostability and Thermoactivity in Bacterial Thermoalkalophilic Lipases. PLoS ONE 2013, 8, e85186. [CrossRef]

11. Bilal, M.; Iqbal, H.M.N.; Guo, S.; Hu, H.; Wang, W.; Zhang, X. State-of-the-art protein engineering approaches using biological macromolecules: A review from immobilization to implementation viewpoint. Int. J. Biol. Macromol. 2018, 108, 893-901. [CrossRef]

12. Kumar, A.; Wu, G.; Liu, Z. Synthesis and characterization of cross-linked enzyme aggregates of serine hydroxyl methyltransferase from Idiomerinaleihiensis. Int. J. Biol. Macromol. 2018, 117, 683-690. [CrossRef]

13. Kumar, A.; Zhang, S.; Wu, G.; Wu, C.C.; Chen, J.; Baskaran, R.; Liu, Z. Cellulose binding domain assisted immobilization of lipase (GSlip CBD) onto cellulosic nanogel: Characterization and application in organic medium. Colloids Surf. B Biointerfaces 2015, 136, 1042-1050. [CrossRef]

14. Kumar, A.; Gricajeva, A.; Sadauskas, M.; Malunavicius, V.; Kamyab, H.; Sharma, S.; Sharma, T.; Pant, D. Microbial lipolytic enzymes-Promising energy-efficient biocatalysts in bioremediation. Energy 2020, 192, 116674. [CrossRef]

15. Kumar, A.; Kanwar, S.S. Synthesis of ethyl ferulate in organic medium usingcelite-immobilized lipase. Biores. Technol. 2011, 102, 2162-2167. [CrossRef] [PubMed]

16. Garcia-Galan, C.; Berenguer-Murcia, A.; Fernandez-Lafuente, R.; Rodrigues, R.C. Potential of Different Enzyme Immobilization Strategies to Improve Enzyme Performance. Adv. Synth. Catal. 2011, 353, 2885-2904. [CrossRef]

17. Rodrigues, R.C.; Berenguer-Murcia, B.; Carballares, D.; Morellon-Sterling, R.; Fernandez-Lafuente, R. Stabilization of enzymes via immobilization: Multipoint covalent attachment and other stabilization strategies. Biotechnol. Adv. 2021, 52, 10782. [CrossRef]

18. Yamaguchi, H.; Kiyota, Y.; Miyazaki, M. Techniques for Preparation of Cross-Linked Enzyme Aggregates and Their Applications in Bioconversions. Catalysts 2018, 8, 174. [CrossRef]

19. Schoevaart, R.; Wolbers, M.W.; Golubovic, M.; Ottens, M.; Kieboom, A.P.; van Rantwijk, F.; van der Wielen, L.A.; Sheldon, R.A. Preparation, optimization, and structures of cross-linked enzyme aggregates (CLEAs). Biotechnol. Bioeng. 2004, 87, 754-762. [CrossRef]

20. Sheldon, R.A. Characteristic features and biotechnological applications of cross-linked enzyme aggregates (CLEAs). Appl. Microbiol. Biotechnol. 2011, 92, 467-477. [CrossRef] [PubMed]

21. Bilal, M.; Iqbal, H.M.N. Tailoring Multipurpose Biocatalysts via Protein Engineering Approaches: A Review. Catal. Lett. 2019, 149, 2204-2217. [CrossRef]

22. Verma, R.; Kumar, A.; Kumar, S. Synthesis and characterization of cross-linked enzyme aggregates (CLEAs) of thermostable xylanase from Geobacillus thermodenitrificans X1. Process Biochem. 2019, 80, 72-79. [CrossRef]

23. Talekar, S.; Joshi, G.; Joshi, A.; Kamat, P. Parameters in preparation and characterization of cross-linked enzyme aggregates (CLEAs). RSC Adv. 2013, 3, 12485-12511. [CrossRef]

24. Mahmod, S.S.; Yusof, F.; Jami, M.S.; Khanahmadi, S. Optimizing the preparation conditions and characterization of a stable and recyclable cross-linked enzyme aggregate (CLEA)-protease. Bioresour. Bioprocess. 2016, 3, 1-11. [CrossRef]

25. Migneault, I.; Dartiguenave, C.; Bertrand, M.J.; Waldron, K.C. Glutaraldehyde: Behavior in aqueous solution, reaction with proteins, and application to enzyme crosslinking. Biotechniques 2004, 37, 798-802. [CrossRef] [PubMed] 
26. Qian, J.; Zhao, C.; Ding, J.; Chen, Y.; Guo, H. Preparation of nano-enzyme aggregates by crosslinking lipase with sodium tripolyphosphate. Process Biochem. 2020, 97, 19-26. [CrossRef]

27. Yan, E.; Cao, H.; Zhang, C.; Lu, Q.; Ye, Y.; He, J.; Huang, L.; Yin, D. Cross-linked protein crystals by glutaraldehyde and their applications. RSC Adv. 2015, 5, 26163-26174. [CrossRef]

28. Aytar, B.S.; Ufuk, B. Preparation of cross-linked tyrosinase aggregates. Process Biochem. 2008, 43, 125-131. [CrossRef]

29. Kartal, F.; Kilinc, A. Crosslinked aggregates of Rhizopus oryzae lipase as industrial biocatalysts: Preparation, optimization, characterization, and application for enantioselective resolution reactions. Biotechnol. Prog. 2012, 28, 937-945. [CrossRef]

30. Kartal, F.; Janssen, M.H.; Hollmann, F.; Sheldon, R.A.; Kılınc, A. Improved esterification activity of Candida rugosa lipase in organic solvent by immobilization as cross-linked enzyme aggregates (CLEAs). J. Mol. Catals. B Enzym. 2011, 71, 85-89. [CrossRef]

31. Gupta, P.; Dutt, K.; Misra, S.; Raghuwanshi, S.; Saxena, R.K. Characterization of cross-linked immobilized lipase from thermophilic mould Thermomyces lanuginosa using glutaraldehyde. Bioresour. Technol. 2009, 100, 4074-4076. [CrossRef]

32. Prabhavathi Devi, B.L.A.; Guo, Z.; Xu, X. Characterization of Cross-Linked Lipase Aggregates. J. Am. Oil Chem. Soc. 2009, 86, 637-642. [CrossRef]

33. Quintana-Castro, R.; Díaz, P.; Valerio-Alfaro, G.; García, H.S.; Oliart-Ros, R.M. Gene cloning, expression, and characterization of the Geobacillus thermoleovorans CCR11 thermoalkaliphilic lipase. Mol. Biotechnol. 2009, 42, 75-83. [CrossRef]

34. Badillo-Zeferino, G.L.; Ruiz-López, I.I.; Oliart-Ros, R.M.; Sánchez-Otero, M.G. Improved expression and immobilization of Geobacillus thermoleovorans CCR11 thermostable recombinant lipase. Biotechnol. Appl. Biochem. 2017, 64, 62-69. [CrossRef] [PubMed]

35. SABLE. Available online: http:// sable.cchmc.org/ (accessed on 23 October 2021).

36. Eswar, N.; Eramian, D.; Webb, B.; Shen, M.Y.; Sali, A. Protein structure modeling with MODELLER. In Structural Proteomics: High-Throughput Methods, 1st ed.; Kobe, B., Guss, M., Huber, T., Eds.; Springer Science \& Business Media: New York, NY, USA, 2008; pp. 145-159.

37. Ribeiro, M.H.L.; Rabaça, M. Cross-linked enzyme aggregates of naringinase: Novel biocatalysts for naringin hydrolysis. Enzyme Res. 2011, 2011, 1-8. [CrossRef]

38. Cruz, J.; Barbosa, O.; Rodrigues, R.C.; Fernandez-Lafuente, R.; Torres, R.; Ortiz, C. Optimized preparation of CALB-CLEAs by response surface methodology: The necessity to employ a feeder to have an effective crosslinking. J. Mol. Catal. B Enzym. 2012, 80,7-14. [CrossRef]

39. Mahmod, S.S.; Yusof, F.; Jami, M.S.; Khanahmadi, S.; Shah, H. Development of an immobilized biocatalyst. with lipase and protease activities as a multipurpose cross-linked enzyme aggregate (multi-CLEA). Process Biochem. 2015, 50, $2144-2157$. [CrossRef]

40. Boudrant, J.; Woodley, J.M.; Fernandez-Lafuente, R. Parameters necessary to define an immobilized enzyme preparation. Process Biochem. 2020, 90, 66-80. [CrossRef]

41. Khanahmadi, S.; Yusof, F.; Amid, A.; Mahmod, S.S.; Mahat, M.K. Optimized preparation and characterization of CLEA-lipase from cocoa pod husk. J. Biotechnol. 2015, 202, 153-161. [CrossRef]

42. Castro-Ochoa, L.D.; Rodríguez-Gómez, C.; Valerio-Alfaro, G.; Oliart-Ros, R.M. Screening, purification and characterization of the thermoalkaliphilic lipase produced by Bacillus thermoleovorans CCR11. Enzyme Microb. Technol. 2005, 37, 648-654. [CrossRef]

43. Espinosa-Luna, G.; Sánchez-Otero, M.G.; Quintana-Castro, R.; Matus-Toledo, R.E.; Oliart-Ros, R.M. Gene Cloning and Characterization of the Geobacillus thermoleovorans CCR11 Carboxylesterase CaesCCR11, a New Member of Family XV. Mol. Biotechnol. 2016, 58, 37-46. [CrossRef] [PubMed]

44. Facchini, F.D.A.; Pereira, M.G.; Vici, A.C.; Filice, M.; Pessela, B.C.; Guisan, J.M.; Fernandez-Lorente, G.; Polizeli, M.D.L. Immobilization Effects on the Catalytic Properties of Two Fusarium Verticillioides Lipases: Stability, Hydrolysis, Transesterification and Enantioselectivity Improvement. Catalysts 2018, 8, 84. [CrossRef]

45. Mahadevan, G.D.; Neelagund, S.E. Thermostable lipase from Geobacillus sp. Iso5: Bioseparation, characterization and native structural studies. J. Basic Microbiol. 2010, 54, 386-396. [CrossRef]

46. Crichton, R.R. Basic coordination chemistry for biologist. In Biological Inorganic Chemistry: A New Introduction to Molecular Structure and Function, 2nd ed.; Elsevier: Amsterdam, The Netherlands, 2012; pp. 21-34.

47. Kanmani, P.; Ramya, S.; Dhivya, R.; Iswarya, M.K.; Sree, V.N.; Subashini, D.; Swetha, K.V. Rice Bran Lipase: Partial Purification, Immobilization in Calcium Alginate Beads, Characterization and Application as a Detergent Additive. World Appl. Sci. J. 2015, 33, 1052-1058. [CrossRef]

48. Lopes, D.B.; Fraga, L.P.; Fleuri, L.F.; Macedo, G.A. Lipase and esterase: To what extent can this classification be applied accurately. Food Sci. Technol. 2011, 31, 603-613. [CrossRef]

49. Zhu, Y.; Li, H.; Ni, H.; Xiao, A.; Li, L.; Cai, H. Molecular cloning and characterization of a thermostable lipase from deep-sea thermophile Geobacillus sp. EPT9. World J. Microbiol. Biotechnol. 2015, 31, 295-306. [CrossRef]

50. Bussamara, R.; Dall'agnol, L.; Schrank, A.; Fernandes, K.F.; Vainstein, M.H. Optimal Conditions for continuous immobilization of Pseudozyma hubeiensis (Strain HB85A) lipase by adsorption in a packed-bed reactor by response surface methodology. Enzyme Res. 2012, 2012, 178. [CrossRef]

51. Hussein, A.H.; Lisowsk, B.K.; Leak, D.J. The Genus Geobacillus and their Biotechnological Potential. Adv. Appl. Microbiol. 2015, 92, 1-48. [CrossRef] 
52. Sivaramakrishnan, R.; Muthukumar, K. Isolation of thermo-stable and solvent-tolerant Bacillus sp. lipase for the production of biodiesel. Appl. Biochem. Biotech. 2011, 166, 1095-1111. [CrossRef]

53. Illanes, A. Enzyme Biocatalysis Principles and Applications, 1st ed.; Springer Science \& Business Media: Amsterdam, The Netherlands, 2008; p. 391.

54. Xu, D.Y.; Yang, Y.; Yang, Z. Activity and stability of cross-linked tyrosinase aggregates in aqueous and nonaqueous media, $J$. Biotechnol. 2011, 152, 30-36. [CrossRef] [PubMed]

55. Yusof, F.; Khanahmadi, S.; Amid, A.; Mahmod, S.S. Cocoa pod husk, a new source of hydrolase enzymes for preparation of cross-linked enzyme aggregate. SpringerPlus 2016, 5, 1621-1623. [CrossRef]

56. Liu, J.; Run-Tian, M.; Yan-Ping, S. Recent advances on support materials for lipase immobilization and applicability as biocatalysts in inhibitors screening methods-A review. Anal. Chim. Acta 2020, 1101, 9-22. [CrossRef] [PubMed]

57. Jamwal, S.; Dharela, R.; Gupta, R.; Ahn, J.H.; Chauhan, G.S. Synthesis of crosslinked lipase aggregates and their use in the synthesis of aspirin. Chem. Eng. Res. Des. 2015, 97, 159-164. [CrossRef]

58. Yang, X.; Zheng, P.; Ni, Y.; Sun, Z. Highly efficient biosynthesis of sucrose-6-acetate with cross-linked aggregates of Lipozyme TL 100 L. J. Biotechnol. 2012, 161, 27-30. [CrossRef] [PubMed]

59. Lewis, L.M.; Johnson, R.E.; Oldroyd, M.E.; Ahmed, S.S.; Joseph, L.; Saracovan, I.; Sinha, S. Characterizing the freeze-drying behavior of model protein formulations. AAPS PharmSciTech 2010, 11, 1580-1590. [CrossRef]

60. Nawani, N.; Rajvinder, R.; Kaur, J. Immobilization and stability studies of a lipase from thermophilic Bacillus sp.: The effect of process parameters on immobilization of enzyme. Electron. J. Biotechnol. 2006, 9, 1-7. Available online: https://scielo.conicyt.cl/ pdf/ejb/v9n5/a11.pdf (accessed on 8 November 2021).

61. Lowry, O.H.; Rosebrough, N.J.; Farr, A.L.; Randall, R.J. Protein Measurement with the Folin Phenol Reagent. J. Biol. Chem. 1953, 193, 265-275. [CrossRef]

62. López-Serrano, P.; Cao, L.; Van-Rantwijk, F.; Sheldon, R.A. Cross-linked enzyme aggregates with enhanced activity: Application to lipases. Biotechnol. Lett. 2002, 24, 1379-1383. [CrossRef]

63. Fang, K.; Lin, D.; Winker, P. Uniform design: Theory and application. Technometrics 2000, 42, 237-248. [CrossRef]

64. Sánchez-Otero, M.G.; Valerio-Alfaro, G.; García-Galindo, H.S.; Oliart-Ros, R.M. Immobilization in the presence of Triton X-100: Modifications in activity and thermostability of Geobacillus thermoleovorans CCR11 lipase. J. Ind. Microbiol. Biotechnol. 2008, 35, 1687-1693. [CrossRef] 